\title{
Diagnostic Value of Widal Test in the Diagnosis of Typhoid Fever: A Systematic Review
}

Hylemariam Mihiretie Mengist ${ }^{1 *}$ and Kelemu Tilahun ${ }^{2}$

${ }^{1}$ Department of Medical Laboratory Sciences, Wollega University, Nekemte, Ethiopia

${ }^{2}$ Department of Public Health, Wollega University, Nekemte, Ethiopia

\begin{abstract}
Introduction: Typhoid fever the common cause of morbidity and mortality especially in the developing countries where Widal test is routinely used as diagnostic tool to rule out the disease. The diagnostic ability of Widal test is debatable as the test method has a low sensitivity, specificity and positive predictive value (PPV). Therefore, reviewing articles across the world regarding the diagnostic value of Widal test is necessary.
\end{abstract}

Methods: Systematic review of published articles regarding the diagnostic value of Widal test to rule out typhoid fever was carried out. Published articles were identified from PubMed, Google scholar, HINARI and other sources. The mean, median, percentile and standard deviation of sensitivity, specificity, NPV and PPV of the reviewed articles were computed by SPSS software version 24 .

Results: A total of 16 articles were included in the systematic review with the oldest publication in the year 1994 and the recent in 2015. The mean sensitivity, specificity, positive predictive value (PPV) and negative predictive value (NPV) of Widal test was $73.5 \%, 75.7 \%, 60 \%$ and $75.2 \%$, respectively.

Conclusion: The systematic review results show that the reliability of Widal test is comparatively poor. Therefore, Widal test should not be used as a diagnostic tool to rule out typhoid fever unless supported by invasive clinical pictures and other confirmatory tests.

Keywords: Diagnostic value; Widal test; Typhoid fever

\section{Introduction}

Typhoid fever is a systemic disease caused by Salmonella typhi and is the major cause of morbidity and mortality worldwide [1]. Reports by the World Health Organization revealed that about 21 million cases and $>600,000$ annual deaths from typhoid fever occur throughout the world. Developing nations share the highest burden due to rapid population growth, increased urbanization, and limited safe water and health systems $[2,3]$.

Accurate diagnosis of typhoid fever at an early stage is important not only for etiological diagnosis, but also to identify individuals that may serve as potential carriers, who may be responsible for acute typhoid fever outbreaks. Additionally, the diagnosis of typhoid fever on clinical grounds is difficult, as the presenting symptoms are diverse and similar to those observed with other febrile illnesses. Serodiagnosis of typhoid fever has been attempted since the late nineteenth century by Widal and Secard. The test is based on demonstrating the presence of agglutinins (antibodies) in the serum of an infected patient, against the $\mathrm{H}$ (flagellar) and $\mathrm{O}$ (somatic) antigens of Salmonella enterica serotype typhi (S. typhi) [4-8].

Widal test relies on the demonstration of a rising titer of antibodies in paired samples 10 to 14 days apart. In typhoid fever, however, such a rise is not always demonstrable, even in blood culture-confirmed cases. In addition, interpreting the test has been such a problem that different cut-offs have been reported from different places which makes difficulty in patient management. Furthermore, the test has a low sensitivity, specificity and positive predictive value (PPV) [9-12] which may create over diagnosis of typhoid fever, patient dissatisfaction, inappropriate economic loss and drug resistance in particular.

In the developed nations, Widal test is no longer used as a diagnostic tool due to the low prevalence of typhoid, access to safe drinking water, better laboratory facilities to isolate the bacteria, and the low sensitivity and specificity of the Widal test [13]. This is not the fact in developing countries including Ethiopia where Widal test is routinely used to diagnose typhoid fever; although, the diagnostic value of the test has been debated. Hence, reviewing articles across the world regarding the diagnostic value of Widal test is necessary.

\section{Methods}

\section{Study design and data source}

Systematic review of the published literature of observational studies was conducted. Original studies providing data on the diagnostic value of Widal test were identified through a computerized search using databases of Medline/PubMed, Google Scholar, HINARI (Health Inter Network Access to Research Initiative) and manual search with detailed search-strategy and cross-checking of reference lists. The search terms used to search the database were diagnostic value, sensitivity, specificity, positive predictive value (PPV) and negative predictive value (NPV) and test efficiency of Widal test. The data abstraction was performed from September, 2015-July, 2016.

\section{Study selection}

A systematic review was made on observational studies which were

*Corresponding authors: Mengist HM, Department of Medical Laboratory Sciences, Wollega University, Nekemte, Ethiopia, Tel: 251576617981; E-mail: hylemariam@gmail.com

Received September 08, 2016; Accepted February 01, 2017; Published February 06, 2017

Citation: Mengist HM, Tilahun K (2017) Diagnostic Value of Widal Test in the Diagnosis of Typhoid Fever: A Systematic Review. J Med Microb Diagn 6: 248 doi:10.4172/2161-0703.1000248

Copyright: (c) 2017 Mengist HM, et al. This is an open-access article distributed under the terms of the Creative Commons Attribution License, which permits unrestricted use, distribution, and reproduction in any medium, provided the original author and source are credited. 


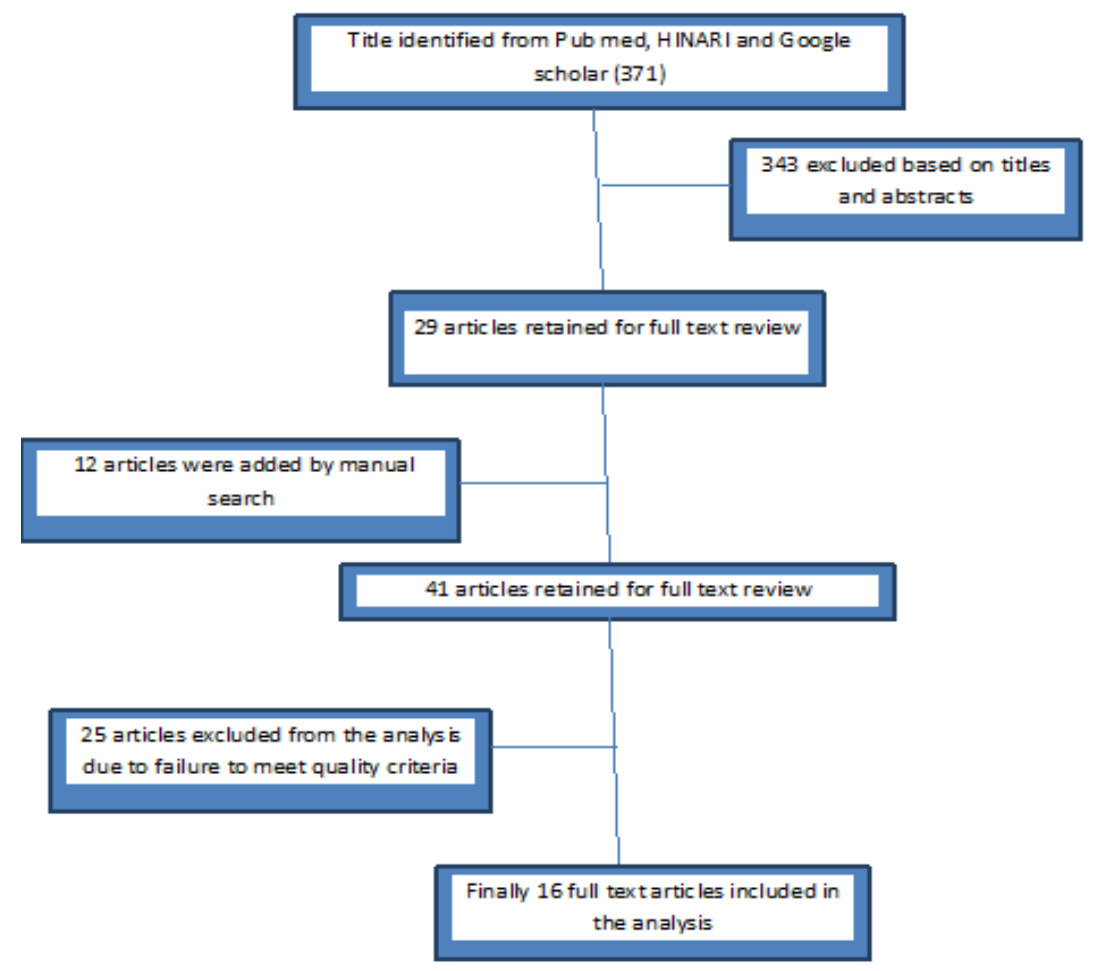

Figure 1: Flow chart diagram describing selection of studies for a systematic review.

reported on the diagnostic value of Widal test in diagnosing typhoid fever. Eligibility criteria for articles to be included in the review were articles presenting data on the sensitivity, specificity, PPV and NPV of Widal test compared to other tests independent of study design and without restriction of publication date. Reports of original studies and review articles written in English language were considered. Studies available only in abstract form, unpublished theses, dissertations and articles with sample size of less than 60 were also excluded (Figure 1).

\section{Methodological quality assessment}

Using culture method as a gold standard, sample size and use of right statistical measurement to assess the diagnostic performance of Widal test were noted as quality of indicators. All assessments were entered into pre-formatted standardized data extraction forms. Studies were assessed for quality and studies fulfilling $75 \%$ of quality assessment parameters were included for analysis. High quality studies were: studies that reported outcomes on at least 50 samples, cross-sectional studies and surveillances whose response rate were greater than $80 \%$ and used culture as a gold standard.

\section{Data abstraction}

The data abstraction was conducted independently by two of the investigators (HMM, KT). The selected studies were reviewed by using pretested and standardized abstraction form to extract data about title; authors, year of publication, country, study design, study site, study base (population-based or hospital-based), sample size, data collection procedure and response rates. When there was a discrepancy in data abstraction, it was resolved through consensus among the team of investigators.

\section{Statistical analysis}

Epi-info version 3.5.1 and SPSS version 24 software's were used for data entry and analysis, respectively. The mean, standard deviation, range and median sensitivity, specificity, NPV and PPV of the articles were drawn. The difference was measured using $\mathrm{P}$ value $\leq$ as a significance level.

\section{Results and Discussion}

\section{Summary of articles included in the analysis}

A total of 16 articles were included in the systematic review with the oldest publication in the year 1994 and the recent in 2015. The reviewed articles included 50 sample size with the smallest and 1735 samples with the largest. Ten cross sectional and 6 case control studies were reviewed (Table 1).

\section{Sensitivity, specificity, PPV and NPV}

Sensitivity is the probability that a truly infected individual will test positive whereas specificity is the probability that a truly uninfected individual will test negative. Positive predictive value (PPV) is the probability that those testing positive by the test are truly infected and Negative predictive value (NPV) is the probability that those testing negative by the test are truly uninfected.

The mean sensitivity Widal test is $73.5 \pm 12.6$ (95\% CI: 60.9-86.1). The probability of a true typhoid patient to be positive by Widal test ranges from $60.9 \%$ to $86.1 \%$. Therefore $13.9 \%$ to $39.1 \%$ of true typhoid patients will be falsely negative by Widal test. The lowest sensitivity of Widal test was $45.2 \%$ and the highest is $98 \%$. The mean ability of Widal test to declare Salmonella uninfected febrile patients as negative falls between $55.5 \%$ to $95.9 \%$. This indicates that $4.1 \%$ to $44.5 \%$ of true negatives test falsely positive by this method compared to blood/stool culture methods. The lowest specificity of Widal test was $13.8 \%$ and the highest was $98 \%$. The mean PPV of the Widal test is $60 \% \pm 29 \%(95 \%$ CI: $31 \%$ to $89 \%)$ and the mean NPV of Widal test is $75.2 \% \pm 24.8 \%$ (95\% CI: $50.4 \%$ to $100 \%$ ) (Table 2). 


\begin{tabular}{|c|c|c|c|c|c|c|c|c|c|c|}
\hline Authors & Year & Country & Design & $\begin{array}{l}\text { Comparison } \\
\text { Method }\end{array}$ & $\begin{array}{l}\text { Sen } \\
(\%)\end{array}$ & $\begin{array}{c}\text { Spec } \\
(\%)\end{array}$ & $\begin{array}{l}\text { NPV } \\
(\%)\end{array}$ & $\begin{array}{l}\text { PPV } \\
(\%)\end{array}$ & Summary of Conclusion & $\begin{array}{l}\text { Ref. } \\
\text { No. }\end{array}$ \\
\hline Ramyi et al. & 2013 & Nigeria & $\begin{array}{l}\text { Cross } \\
\text { sectional }\end{array}$ & Stool culture & 71.4 & 66.7 & 50 & 83 & $\begin{array}{l}\text { Although Widal test is sensitive, it not } \\
\text { relevant to diagnose typhoid alone }\end{array}$ & [13] \\
\hline Wasihun et al. & 2015 & Ethiopia & $\begin{array}{l}\text { Cross } \\
\text { sectional }\end{array}$ & Blood culture & 75 & 95.9 & 99.6 & 22.2 & $\begin{array}{l}\text { Patients were wrongly diagnosed and } \\
\text { treated for typhoid fever by Widal }\end{array}$ & [14] \\
\hline Aziz and Haque & 2012 & India & $\begin{array}{l}\text { Cross } \\
\text { sectional }\end{array}$ & Blood culture & 71 & 62 & 31 & 91 & $\begin{array}{l}\text { Widal test is relevant as a diagnostic } \\
\text { tool for typhoid fever }\end{array}$ & {$[15]$} \\
\hline $\begin{array}{l}\text { Gopala Krishnan } \\
\text { et al. }\end{array}$ & 2002 & Malaysia & $\begin{array}{l}\text { Cross } \\
\text { sectional }\end{array}$ & Blood culture & 98 & 76 & 98 & 69 & $\begin{array}{c}\text { Typhoid is less time consuming and } \\
\text { easier than Widal test }\end{array}$ & [16] \\
\hline Keddy et al. & 2011 & South Africa & $\begin{array}{l}\text { Cross } \\
\text { sectional }\end{array}$ & Blood culture & 95.2 & 13.8 & 70.2 & 57.1 & $\begin{array}{l}\text { Both slide and tube Widal tests } \\
\text { performed poorly }\end{array}$ & [17] \\
\hline Kulkarni and Rego & 1994 & Karnataka & Case control & Blood culture & 83.3 & 81 & 94.2 & 56.8 & $\begin{array}{c}\text { Widal test is one of the best, easy, } \\
\text { cheap and simple method to diagnose } \\
\text { typhoid fever }\end{array}$ & [18] \\
\hline $\begin{array}{l}\text { Andualem } \\
\text { et al. }\end{array}$ & 2014 & Ethiopia & $\begin{array}{l}\text { Cross } \\
\text { sectional }\end{array}$ & Blood culture & 71.4 & 68.4 & 98.9 & 5.7 & $\begin{array}{l}\text { Widal test has a low sensitivity, } \\
\text { specificity and PPV but good NPV }\end{array}$ & [3] \\
\hline Ley et al. & 2010 & Tanzania & $\begin{array}{l}\text { Cross } \\
\text { sectional }\end{array}$ & Blood culture & 75 & 98 & 100 & 26 & $\begin{array}{l}\text { Widal test performed well in terms of } \\
\text { sensitivity, specificity, and NPV. }\end{array}$ & [9] \\
\hline Sherwal et al. & 2004 & India & Case control & Blood culture & 74 & 83 & ND & ND & $\begin{array}{c}\text { Typhoid is more reliable than Widal test } \\
\text { for typhoid fever }\end{array}$ & [19] \\
\hline Parry et al. & 1999 & Vietnam & Case control & Blood culture & 74 & 95 & 90 & 86 & $\begin{array}{l}\text { Widal test is helpful for presumptive } \\
\text { diagnosis }\end{array}$ & [20] \\
\hline Al-Yasiri & NP & Najaf city & Case control & Blood culture & 74 & 95 & 90 & 86 & $\begin{array}{l}\text { Widal test can be valuable in the } \\
\text { absence of culture }\end{array}$ & [21] \\
\hline Alam et al. & 2011 & Dhaka & Case control & Blood culture & 65 & 76.4 & 31.7 & 81.1 & $\begin{array}{l}\text { The Widal test can be of diagnostic } \\
\text { value in the absence of culture }\end{array}$ & [22] \\
\hline $\begin{array}{l}\text { Bhutta and } \\
\text { Mansurali }\end{array}$ & 1999 & Pakistan & $\begin{array}{l}\text { Cross } \\
\text { sectional }\end{array}$ & Blood culture & 63 & 81 & 55 & 85 & $\begin{array}{l}\text { Widal test is not sensitive and not } \\
\text { specific }\end{array}$ & [23] \\
\hline House et al. & 2001 & Vietnam & Case control & Serology & 60 & 90 & 70 & 84 & $\begin{array}{c}\text { Widal test is not reliable compared to } \\
\text { other tests }\end{array}$ & [24] \\
\hline Adhikari et al. & 2015 & Nepal & $\begin{array}{l}\text { Cross } \\
\text { sectional }\end{array}$ & Blood culture & 45.2 & 82.3 & 87.8 & 34.2 & $\begin{array}{l}\text { Widal test is not sensitive enough for an } \\
\text { endemic areas for typhoid fever }\end{array}$ & [25] \\
\hline Sanjeev et al. & 2013 & India & $\begin{array}{l}\text { Cross } \\
\text { sectional }\end{array}$ & Blood culture & 78.7 & 58.8 & ND & ND & $\begin{array}{l}\text { Widal test is not reliable when } \\
\text { compared to blood culture and typhoid }\end{array}$ & [26] \\
\hline
\end{tabular}

Table 1: Summary the observational studies assessing the value of Widal test in the diagnosis of typhoid fever included in the systematic review.

\begin{tabular}{|c|c|c|c|c|c|}
\hline Measurement & & Sensitivity & Specificity & NPV & PPV \\
\hline Mean & & 73.5 & 75.7 & 75.2 & 60 \\
\hline Median & & 74 & 81 & 87 & 69 \\
\hline SD & & 12.6 & 20.2 & 24.8 & 29 \\
\hline Minimum & & 45.2 & 13.8 & 31 & 5.7 \\
\hline Paximum & & 98 & 98 & 100 & 91 \\
\hline & 25 & 66.5 & 67 & 52.5 & 30 \\
\hline & 50 & 74 & 81 & 87.8 & 69 \\
\hline
\end{tabular}

SD: Standard Deviation; PPV: Positive Predictive Value; NPV: Negative Predictive Value

Table 2: Analysis of Widal test performance reported by articles included in the review.

\section{Conclusion}

The systematic review results show that the reliability of Widal test is comparatively poor. The mean sensitivity, specificity, NPV and PPV of Widal test remains below $80 \%$. The efficiency of Widal test in diagnosing typhoid fever without other confirmatory tests is not of diagnostic value. Therefore, Widal test should not be used as a diagnostic tool to rule out typhoid fever unless supported by invasive clinical pictures and other confirmatory tests.

\section{Competing Interests}

Authors declare that they have no conflict of interest associated with the publication of this manuscript.

\section{Authors' Contribution}

Conceived and designed the experiments: HMM. Performed the experiments: HMM. Analyzed the data: HMM. Contributed reagents/materials/analysis tools: HMM, KT. Wrote the paper: HMM. Assisted with design, analysis, and interpretation of data: KT. Critical review of the manuscript: HMM, KT. Read and approved the final manuscript: HMM, KT. Critical appraisal of the manuscript: HMM, KT.

\section{Acknowledgement}

We want to acknowledge Wollega University for providing internet service and administrative support. We are glad to thank authors of articles reviewed in advance.

\section{References}

1. Bhanu S, Vandana S, Archana S (2011) Comparative study of the diagnostic procedures in salmonella infection, causative agent. An overview study. IRJP 2: $127-129$.

2. Udeze AO, Abdulrahman F, Okonko LO, Anibijuwon Jl (2010) Sero prevalence of Salmonella typhi and Salmonella paratyphi among the First Year Students of University of Ilorin, Ilorin - Nigeria. Middle East J Sci Res 6: 257-262.

3. Andualem G, Abebe T, Kebede N, Gebre-Selassie S, Mihret A, et al. (2014) A comparative study of Widal test with blood culture in the diagnosis of typhoid fever in febrile patients BMC Res Notes 7: 653.

4. Topley, Wilson (1990) Principles of Bacteriology, virology and immunity. [ $\left.4^{\text {th }} e d n\right]$

5. Parry CM, Hien MB, Dougan MD, White NJ, Farrar MT (2002) Typhoid fever. N EnglJ Med 347: 1770-1782.

6. Hunter PR (1963) Fernand Widal. Med Hist 7: 56-61.

7. Manson-Bahr PEC, Bell DR (1987) Manson's tropical diseases. [19 $9^{\text {th }}$ edn] London: Bailliere- Tindall 194-206. 
8. Gilman $\mathrm{RH}$, Terminel $\mathrm{M}$, Levine MM, Hernandez-Mendoza P, Hornick R (1975) Comparison of relative efficacy of blood, stool, urine, bone marrow and rose spot cultures for recovery of Salmonella typhi in typhoid fever. Lancet 1: 1211-1213.

9. Ley B, Mtove G, Thriemer K, Thriemer K, Amos B, et al. (2010) Evaluation of the Widal tube agglutination test for the diagnosis of typhoid fever among children admitted to a rural hospital in Tanzania and a comparison with previous studies. BMC Infect Dis 10: 180 .

10. Olopoenia LA, King AL (2000) Widal agglutination test - 100 years later: stil plagued by controversy. Postgrad Med J 76: 80-84

11. Bhutta ZA (2006) Current concepts in the diagnosis and treatment of typhoid fever. BMJ 333:78-82.

12. Ujiwala N, Gaikwad, Rajurkar M (2014) Diagnostic efficacy of Widal slide agglutination test against Widal tube agglutination test in enteric fever. Int $J$ Med Public Health 4: 227-230.

13. Ramyi MS, Ihuoma OJ, Ogundeko TO, Ameh JM, Ampu TY, et al. (2013) Comparative Study on the use of Widal Test and stool culture in the laboratory diagnosis of salmonella infection in adult and children in Jos metropolis, Plateau State, Nigeria. IJSR 2: 435-441.

14. Wasihun AG, Wkidan LN, Gebremariam SA, Wolderufael AL, Muthupandian S et al. (2015) Diagnosis and treatment of typhoid fever and associated prevailing drug resistance in Northern Ethiopia. Int J Infect Dis 35: 96-102.

15. Aziz T, Haque SS (2012) Role of widal test in the diagnosis of typhoid fever in context to other test. Am J Biochem Biotechnol 2: 16-18.

16. Gopala Krishnan V, Sekhar WY, SooEH, VinsentRA, Devi S (2002) Typhoid fever in Kuala Lumpur and a comparative evaluation of two commercial diagnostic kits for the detection of antibodies to Salmonella typhi. Singapore Med J 43: 354-358.
17. Keddy KH, Sooka A, Letsoalo ME, Hoyland G, Chaignat CL, et al. (2011) Sensitivity and specificity of typhoid fever rapid antibody tests for laboratory diagnosis at two sub-Saharan African sites. WHO Bulletin 11: 1-15.

18. Kulkarni ML, Rego SJ (1994) Value of single Widal test in the diagnosis of typhoid fever. Indian Pediatr 31: 1373-1377.

19. Sherwal BL, Dhamija RK, Randhawa VS, Jais M, Kaintura A, et al. (2004) Comparative study of typhidot and widal test in patients of typhoid fever. JIACM 5: 244-246.

20. Parry CM, Hoa NTT, Diep TS, Wain J, Chinh NT, et al. (1999) Value of a singletube widal test in diagnosis of typhoid fever in Vietnam. J Clin Microbiol 37: 2882-2886.

21. Al-Yasiri IK (2011) Significance and value of the Widal test in the diagnosis of typhoid fever in a rural area in Najaf city. Unpublished data.

22. Alam AS, Rupam FA, Chaiti F (2011) Utility of a single Widal test in the diagnosis of typhoid Fever. Bangladesh. J Child Health 35: 53-58.

23. Bhutta ZA, Mansurali N (1999) Rapid serologic diagnosis of pediatric typhoid fevers in an endemic area: A prospective comparative evaluation of two dotenzyme immunoassays and the Widal test. Am J Trop Med Hyg 61: 654-657.

24. House D, Wain J, HO VA, Diep TS, Chinh NT, et al. (2001) Serology of typhoid fever in an area of endemicity and its relevance to diagnosis. J Clin Microbio 39: 1002-1007.

25. Adhikari A, Rauniyar R, Raut PP, Manadhar KD, Gupta BP (2015) Evaluation of sensitivity and specificity of ELISA against Widal test for typhoid diagnosis in endemic population of Kathmandu. BMC Infect Dis 15: 523

26. Sanjeev H, Nayak S, Paiasha KB, Rekha R, Karnaker V, et al. (2013) A systematic evaluation of rapid Dot-Eia, blood culture and Widal test in the diagnosis of typhoid fever. Nitte University: Journal of Health Science 3: 21-24. 